УдК 342.9

DOI https://doi.org/10.32837/pyuv.v2i3(28).370

Ю. Г. Севрук

здобувач кафедри адміністративного та господарського права

Запорізького національного університету

\title{
ПРАВОВІ ОСНОВИ АДМІНІСТРАТИВНО-ПРАВОВОГО ЗАБЕЗПЕЧЕННЯ РЕАЛІЗАЦІЇ ФУНКЦЙ ПРОКУРАТУРИ УКРАЇНИ
}

Реформа органів прокуратури, яка розпочалась з ухваленням Закону України «Про внесення змін до деяких законодавчих актів України щодо першочергових заходів із реформи органів прокуратури» від 19 вересня 2019 р. № 113-IX, покликана створити якісно нову систему прокуратури України. Конституція України чітко визначає функції прокуратури, які деталізовані в Законі України «Про прокуратуру», проте на практиці іх реалізація потребує ще більшої правової деталізації, що зумовлює необхідність ухвалення Генеральною прокуратурою України цілого масиву підзаконних нормативно-правових актів, зокрема наказів. Наказами Генеральної прокуратури України регламентується порядок здійснення окремих повноважень прокурорів у межах визначених функцій, тому значення таких відомчих нормативних актів важко переоцінити і вони потребують окремого науково аналізу 3 метою виявлення прогалин, колізій і формулювання конкретних пропозицій щодо їх удосконалення відповідно із принципами права, нормами ратифікованих міжнародних актів та положеннями чинних законів України.

Вищезазначене зумовлює актуальність, а також теоретичну та практичну значущість дослідження правових основ адміністративно-правового забезпечення реалізації функцій прокуратури.

Питання адміністративно-правового забезпечення діяльності правоохоронних органів досліджуються в роботах фахівців у сфері адміністративного права, серед яких праці О. Бандурки, В. Бевзенка, М. Віхляєва, Н. Губерської, С. Гусарова, Р. Калюжного, Т. Коломоєць, В. Колпакова, А. Комзюка, О. Кузьменко, В. Курила, Д. Лук'янця, Д. Лученка, П. Лютікова, Р. Мельника, О. Миколенка, Н. Нижник, Д. Приймаченка, С. Стеценко, М. Тищенка, А. Школика й інших вчених-адміністративістів. Проте питання правових засад адміністративно-правового забезпечення реалізації функцій прокуратури досліджено фрагментарно, більшою мірою в рамках більш загальних тем, що актуалізує проведення даного дослідження.

Методологія даного дослідження грунтується на комплексному поєднанні філософських, загальнонаукових і спеціально-юридичних методів дослідження (метод юридичної догматики, ме- тод юридичного моделювання тощо), принципів об'єктивності й історизму.

Метою наукової публікації є дослідження правових основ адміністративно-правового забезпечення реалізації функцій прокуратури України в умовах реформування системи органів кримінальної юстиції.

Конституція України містить вичерпний перелік функцій прокуратури, як-от: підтримання публічного обвинувачення в суді; організація і процесуальне керівництво досудовим розслідуванням, вирішення відповідно до закону інших питань під час кримінального провадження, нагляду за негласними й іншими слідчими і розшуковими діями органів правопорядку; представництво інтересів держави в суді у виключних випадках і в порядку, що визначені законом [1].

Відповідно до ст. 2 Закону України «Про прокуратуру», на прокуратуру покладаються такі функції: підтримання державного обвинувачення в суді; представництво інтересів громадянина або держави в суді у випадках, визначених цим Законом та гл. 12 p. III Цивільного процесуального кодексу України; нагляд за додержанням законів органами, що провадять оперативно-розшукову діяльність, дізнання, досудове слідство; нагляд за додержанням законів під час виконання судових рішень у кримінальних справах, а також під час застосування інших заходів примусового характеру, пов'язаних з обмеженням особистої свободи громадян.

У ч. 3 ст. 3 Закону України «Про прокуратуру» прямо визначено, що на прокуратуру не можуть покладатися функції, не передбачені Конституцією України [2]. Отже, нагляд за додержанням законів під час виконання судових рішень у кримінальних справах, а також у разі застосування інших заходів примусового характеру, пов'язаних з обмеженням особистої свободи громадян, органи прокуратури здійснюють тимчасово, до утворення відповідних органів нагляду Кримінально-виконавчої служби України.

Діяльність прокуратури, згідно зі ст. 3 Закону України «Про прокуратуру», здійснюється на засадах (принципах): верховенства права та визнання людини, її життя і здоров'я, честі і гідності, недоторканності і безпеки найвищою соціальною цінністю; законності, справедливості, неупере- 
дженості й об’єктивності; територіальності; презумпції невинуватості; незалежності прокурорів, що передбачає існування гарантій від незаконного політичного, матеріального чи іншого впливу на прокурора щодо ухвалення ним рішень під час виконання службових обов'язків; політичної нейтральності прокуратури; недопустимості незаконного втручання прокуратури в діяльність органів законодавчої, виконавчої і судової влади; поваги до незалежності суддів, що передбачає заборону публічного висловлювання сумнівів щодо правосудності судових рішень поза межами процедури їх оскарження в порядку, передбаченому процесуальним законом; прозорості діяльності прокуратури, що забезпечується відкритим і конкурсним зайняттям посади прокурора, вільним доступом до інформації довідкового характеру, наданням на запити інформації, якщо законом не встановлено обмежень щодо її надання; неухильного дотримання вимог професійної етики та поведінки [2].

Організація та діяльність прокуратури України, статус прокурорів визначаються Конституцією України, Законом України «Про прокуратуру» й іншими законами України, чинними міжнародними договорами, згода на обов'язковість яких надана Верховною Радою України. Серед новел законодавства України, що регламентує діяльність органів прокуратури, варто зазначити Закон України «Про внесення змін до деяких законодавчих актів України щодо першочергових заходів із реформи органів прокуратури» [3].

До адміністративно-правових засобів організації та діяльності органів прокуратури належать накази Генеральної прокуратури України. «Базовим» наказом є наказ Генеральної прокуратури України № 15 від 19 січня 2017 р. «Про основні засади організації роботи в органах прокуратури України» [4].

У вказаному наказі для забезпечення ефективного виконання покладених на органи прокуратури функцій із метою захисту прав і свобод людини, загальних інтересів суспільства та держави першочергова увага приділяється вдосконаленню організації роботи, управління та контролю виконання, упровадженню їх новітніх форм і методів, зокрема з використанням сучасних інформаційних технологій. Відповідальність за цей напрям роботи покладається безпосередньо на керівників органів прокуратури. Керівники та прокурори прокуратур усіх рівнів зобов'язані забезпечувати періодичне, не менш як двічі на рік, інформування суспільства про діяльність прокуратури шляхом повідомлень у засобах масової інформації з додержанням вимог законодавства, що регламентує правовий статус інформації з обмеженим доступом [4].

Керівники регіональних та місцевих прокуратур повинні не менш як двічі на рік на відкритому пленарному засіданні місцевої ради за участі представників засобів масової інформації інформувати населення відповідної адміністративно-територіальної одиниці про результати діяльності прокуратур шляхом надання узагальнених статистичних і аналітичних даних.

Відповідно до вказаного наказу, робота структурних підрозділів Генеральної прокуратури України та регіональних прокуратур організовується за територіальним та функціональним (предметним) принципами, з урахуванням теоретичної підготовки та практичного досвіду працівників, використовуючи їхню спеціалізацію, закріплення за ними прокуратур нижчого рівня та конкретних напрямів. Обов'язки між керівництвом органів прокуратури розподіляються наказами Генерального прокурора, керівників регіональних і місцевих прокуратур. Розподіл функціональних обов'язків між працівниками структурних підрозділів здійснюється їх керівниками і затверджується в керівництва Генеральної прокуратури України, регіональних прокуратур відповідно до компетенції. Обов'язки між працівниками місцевих прокуратур з урахуванням їх структури розподіляються наказами керівників цих прокуратур або їх перших заступників чи заступників згідно з компетенцією [4].

Отже, адміністративно-правове забезпечення організації та діяльності органів прокуратури всіх рівнів здійснюється за допомогою наказів Генерального прокурора України, керівників регіональних і місцевих прокуратур, що відповідає принципу єдиноначальності.

Не менш важливий для загального адміністративно-правового забезпечення реалізації всіх функцій прокуратури наказ Генеральної прокуратури України № 1/1гн від 16 січня 2013 р. «Про координацію діяльності правоохоронних органів у сфері протидії злочинності та корупції» [5].

3 метою підвищення ефективності координації діяльності правоохоронних органів у сфері протидії злочинності та корупції, відповідно до положень законів України «Про запобігання корупції» та «Про прокуратуру», координація діяльності правоохоронних органів у сфері протидії злочинності та корупції визначена одним із головних пріоритетів у роботі прокурорів усіх рівнів. Організація зазначеної роботи здійснюється з урахуванням норм Положення про координацію діяльності правоохоронних органів у сфері протидії злочинності та корупції.

Відповідно із зазначеним наказом, для прокурорів усіх рівнів основною формою координації діяльності правоохоронних органів є проведення координаційних нарад під особистим головуванням їхніх керівників. На координаційні наради запрошуються керівники органів виконавчої влади й органів місцевого самоврядування для заслуховування інформації щодо їхньої діяльності 
з питань попередження і протидії злочинності та корупції. Зазначені повноваження використовуються для вирішення питань протидії і попередження злочинності та корупції, які потребують застосування повноважень органів державної влади й органів місцевого самоврядування [5].

Однією з основних функцій прокуратури $є$ функція організації і процесуального керівництва досудовим розслідуванням. Правовою основою для адміністративно-правового забезпечення реалізації даної функції є Кримінальний процесуальний кодекс України, Закон України «Про організаційно-правові основи боротьби з організованою злочинністю». Безпосереднім адміністративно-правовим засобом забезпечення реалізації вказаної функції є наказ Генеральної прокуратури № 51 від 28 березня 2019 р. «Про затвердження Порядку організації діяльності прокурорів і слідчих органів прокуратури у кримінальному провадженні» [6].

3 метою забезпечення належної організації діяльності прокурорів у кримінальному провадженні в Генеральній прокуратурі України функціонує Департамент нагляду за додержанням законів у кримінальному провадженні та координації правоохоронної діяльності Генеральної прокуратури України. Контроль за виконанням вказаного наказу покладено на першого заступника та заступників Генерального прокурора, заступника Генерального прокурора - Головного військового прокурора, заступника Генерального прокурора - керівника Спеціалізованої антикорупційної прокуратури, керівників регіональних, місцевих і військових прокуратур.

Важливий для адміністративно-правового забезпечення реалізації функції організації і процесуального керівництва досудовим розслідуванням наказ Генеральної прокуратури України № 4/1гн від 3 грудня 2012 р. зі змінами, внесеними наказами Генерального прокурора України № 4/1гн-1 від 25 січня 2013 р. та № 98 від 13 листопада 2013 р., «Про організацію прокурорського нагляду за додержанням законів органами, які проводять оперативно-розшукову діяльність» [7].

Згідно із зазначеним наказом, перевірки законності проведення оперативно-розшукових заходів і ухвалених водночас рішень проводяться на підставі: планових заходів з урахуванням стану законності в цій сфері діяльності; даних про відсутність позитивних результатів щодо попередження, своєчасного виявлення і припинення злочинів, розшуку осіб, які переховуються від органів досудового розслідування, суду або ухиляються від відбування кримінального покарання, а також безвісно відсутніх осіб; інформації про неналежне виконання вказівок уповноваженого прокурора; повідомлень оперативних підрозділів про заведення чи закриття оперативно-розшукової спра- ви, проведення оперативно-розшукових заходів, які не потребують дозволу слідчого судді або рішення прокурора; повідомлень, скарг і звернень осіб про порушення вимог законодавства під час здійснення оперативно-розшукової діяльності; інформації про неналежне виконання доручень, постанов, ухвал та інших обов'язкових рішень слідчого, прокурора, слідчого судді, суду щодо здійснення розшуку осіб, які переховуються від органів досудового розслідування, суду або ухиляються від відбування кримінального покарання.

Прокурори перевіряють додержання вимог чинного законодавства щодо: заведення оперативно-розшукових справ, підстав для проведення оперативно-розшукової діяльності; наявності повноважень в осіб, які здійснюють оперативно-розшукову діяльність; відповідності оперативно-розшукових заходів цілям і завданням оперативно-розшукової діяльності, дотримання встановлених законодавством умов і порядку проведення оперативно-розшукових заходів, а також залучення громадян до їх здійснення на конфіденційній основі та засадах добровільності; застосування окремих обмежень прав і свобод людини, обгрунтованості клопотань до суду про надання дозволу на проведення оперативно-розшукових заходів, зокрема пов'язаних із втручанням у приватне спілкування; своєчасності направлення відомостей про злочинну діяльність окремих осіб, які здобуті у процесі оперативно-розшукової діяльності, органам досудового розслідування для початку та здійснення досудового розслідування; обгрунтованості продовження, припинення, поновлення обчислення строків ведення оперативно-розшукових справ та їх закриття, а також використання результатів оперативно-розшукової діяльності; своєчасності повідомлення про заведення та закриття оперативно-розшукових справ; відповідності відомчих наказів, інструкцій, розпоряджень та інших правових актів із питань проведення оперативно-розшукової діяльності Конституції України й іншим законам України [7].

Не менш важливий для адміністративно-правового забезпечення реалізації функції організації і процесуального керівництва досудовим розслідуванням спільний наказ Генеральної прокуратури України, Міністерства внутрішніх справ України, Служби безпеки України, Адміністрації державної прикордонної служби України, Міністерства фінансів України та Міністерства юстиції України № 114/1042/516/1199/936/1687/5 від 16 листопада 2012 р. «Про затвердження Інструкції про організацію проведення негласних слідчих (розшукових) дій та використання їх результатів у кримінальному провадженні» [8].

Одним із пріоритетних напрямів діяльності прокуратури України є реалізація передбаченої Конституцією України функції представництва 
інтересів держави в суді та під час виконання судових рішень. Правовою основою адміністративно-правового забезпечення реалізації вказаної функції є ст. ст. 23 та 24 Закону України «Про прокуратуру», Закон України «Про виконавче провадження», Цивільний процесуальний кодекс України, Господарський процесуальний кодекс України, Кодекс адміністративного судочинства України. Безпосереднім адміністративно-правовим засобом реалізації вказаної функції $є$ наказ Генеральної прокуратури України № 186 від 21 вересня 2018 р. «Про організацію діяльності прокурорів щодо представництва інтересів держави в суді та під час виконання судових рішень» [9].

Відповідно до вказаного наказу, з метою забезпечення належної організації діяльності прокурорів щодо представництва інтересів держави в суді та під час виконання судових рішень прокурори здійснюють представницьку діяльність шляхом: пред'явлення позовів (заяв); вступу у справи, порушення за позовами (заявами) інших осіб; ініціювання перегляду судових рішень, зокрема у справах, порушених за позовом (заявою) іншої особи; участі в розгляді справ; участі у виконавчому провадженні під час виконання рішень у справах, у яких прокурором здійснювалося представництво інтересів держави [9].

Адміністративно-правовими засобами забезпечення реалізації функції представництва інтересів держави в суді та під час виконання судових рішень $€$ також вказівки Генеральної прокуратури України, наприклад, вказівка Генеральної прокуратури України № 35 від 6 липня 2005 р. «Щодо активізації представницької діяльності з питань земельних відносин та ефективного застосування всіх передбачених законом засобів захисту прав та інтересів держави і територіальних громад на землю».

Правовою основою реалізації функції прокуратури щодо нагляду за додержанням законів під час виконання судових рішень у кримінальних справах, а також у разі застосування інших заходів примусового характеру, пов'язаних з обмеженням особистої свободи громадян, є Кримінально-виконавчий кодекс України, Закон України «Про попереднє ув'язнення» тощо. Безпосереднім адміністративно-правовим засобом забезпечення реалізації вказаної функції $є$ наказ Генеральної прокуратури України № 161 від 20 квітня 2016 р. «Про організацію діяльності прокурорів з нагляду за додержанням законів при виконанні судових рішень у кримінальних справах, а також при застосуванні інших заходів примусового характеру, пов'язаних з обмеженням особистої свободи громадян» [10].

Відповідно до зазначеного наказу, основними завданнями діяльності на цьому напрямі є забезпечення нагляду за додержанням: прав і свобод людини, загальних інтересів суспільства і держа- ви під час виконання покарань та інших заходів примусового характеру, пов' язаних з обмеженням особистої свободи, відповідно до законів України, міжнародних договорів, згода на обов'язковість яких надана Верховною Радою України; законодавства щодо запобігання катуванням чи нелюдському або такому, що принижує гідність, поводженню чи покаранню із затриманими, взятими під варту та засудженими; визначених законодавством вимог режиму, порядку й умов тримання затриманих осіб, а також осіб, до яких застосовано запобіжні заходи: тримання під вартою; поміщення до психіатричного закладу в умовах, що виключають їх небезпечну поведінку; встановлених законодавством вимог режиму, порядку й умов тримання осіб, до яких застосовано інші заходи примусового характеру; визначених законодавством вимог режиму, порядку й умов тримання, а також відбування покарань засудженими; законодавства щодо виконання покарань, які не пов' язані з позбавленням волі; законодавства під час здійснення оперативно-розшукової діяльності оперативними підрозділами органів і установ виконання покарань та слідчих ізоляторів Державної кримінально-виконавчої служби України; законодавства щодо застосування заходів впливу за адміністративні правопорушення [10].

Нагляд у межах компетенції здійснюють також структурні підрозділи Генеральної прокуратури України з питань нагляду у кримінальному провадженні, захисту прав і свобод дітей (ювенальної юстиції).

Отже, на рівні наказів Генеральної прокуратури України здійснюється адміністративно-правове забезпечення реалізації основних функцій прокуратури. Проаналізовані накази деталізуються на рівні відповідних наказів керівників регіональних і місцевих прокуратур.

Проведене дослідження дозволило сформулювати висновок про те, що правовою основою адміністративно-правового забезпечення реалізації функції прокуратури є Кримінальний процесуальний кодекс України, Цивільний процесуальний кодекс України, Господарський процесуальний кодекс України, Кодекс адміністративного судочинства України, закони України «Про прокуратуру», «Про організаційно-правові основи боротьби з організованою злочинністю», «Про запобігання корупції», «Про виконавче провадження» тощо. Основними адміністративно-правовими засобами забезпечення реалізації функцій прокуратури є накази Генеральної прокуратури України, які деталізуються в наказах керівників регіональних і місцевих прокуратур.

Загальний стан адміністративно-правового забезпечення реалізації функцій прокуратури України задовільний через наявні прогалини в національному законодавстві щодо відсутно- 
сті відповідальності суб'єктів владних повноважень за невиконання законних вимог (запитів, вказівок) прокурора. Позбавлення прокуратури функції загального нагляду зумовило втрату реальних інструментів владного впливу прокурорів на інших представників публічної адміністрації з метою забезпечення дотримання законності та принципу верховенства права. Отже, пріоритетним напрямом удосконалення правових основ адміністративно-правового забезпечення реалізації функцій прокуратури України є внесення змін до процесуальних кодексів України, Закону України «Про прокуратуру» (щодо повернення інституту законних вимог прокурора, які є обов'язковими для всіх органів, підприємств, установ, організацій, посадових осіб та громадян і виконуються невідкладно або в передбачені законом чи визначені прокурором строки (ст. 8 «Обов'язковість виконання вимог прокурора» Закону України «Про прокуратуру» у редакції до 2014 р.), Кодексу України про адміністративні правопорушення (далі - КУпАП) щодо посилення відповідальності суб'єктів владних повноважень за невиконання законних вимог прокурора (ст. 185-8 КУпАП).

Окремого дослідження потребує питання доцільності внесення змін до Конституції України щодо повернення органам прокуратури функції загального нагляду та відповідних повноважень для її реалізації.

\section{Jimepamypa}

1. Конституція України від 28 червня 1996 p. Дата оновлення: 02.12 .2019 p. URL: https://zakon.rada.gov.ua/laws/show/254к/96-вр.

2. Про прокуратуру : Закон України від 14 жовтня 2014 p. № 1697-VII. Дата оновлення: 28.11.2019. URL: https://zakon.rada.gov.ua/laws/show/1697-18.

3. Про внесення змін до деяких законодавчих актів України щодо першочергових заходів із реформи органів прокуратури : Закон України від 19 вересня 2019 р. № $113-I X$. Дата оновлення: 17.10 .2019 р. URL: https://zakon.rada.gov.ua/laws/main/113-IX.

4. Про основні засади організації роботи в органах прокуратури України : наказ Генеральної прокуратури України № 15 від 19 січня 2017 p. URL: https://www.gp.gov.ua/ua/gl.html?_m=publications\&_ $\mathrm{t}=\mathrm{rec} \& \mathrm{id}=94102$.

5. Про координацію діяльності правоохоронних органів у сфері протидії злочинності та корупції : наказ Генеральної прокуратури України № 1/1гн від 16 січня 2013 p. URL: https://www.gp.gov.ua/ua/gl.html? $\mathrm{m}=$ publications\&_t $=\mathrm{rec} \& \mathrm{id}=94102$.

6. Про затвердження Порядку організації діяльності прокурорів і слідчих органів прокуратури у кримінальному провадженні : наказ Генеральної прокуратури № 51 від 28 березня 2019 p. URL: https://www.gp.gov.ua/ ua/gl.html? $\mathrm{m}=$ publications\&_t=rec\&id=94102.

7. Про організацію прокурорського нагляду за додержанням законів органами, які проводять оперативно-розшукову діяльність : наказ Генеральної прокуратури України № 4/1гн від 3 грудня 2012 p. URL: https://www.gp.gov.ua/ua/gl.html? m=publications\&_ $\mathrm{t}=\mathrm{rec} \& \mathrm{id}=94102$.
8. Про затвердження Інструкції про організацію проведення негласних слідчих (розшукових) дій та використання їх результатів у кримінальному провадженні : наказ Генеральної прокуратури України, Міністерства внутрішніх справ України, Служби безпеки України, Адміністрації державної прикордонної служби України, Міністерства фінансів України, Міністерства юстиції України № 114/1042/516/1199/936/1687/5 від 16 листопада 2012 p. URL: https://zakon.rada.gov.ua/ laws/show/v0114900-12.

9. Про організацію діяльності прокурорівщодо представництва інтересів державив суді та при виконанні судових рішень : наказ Генеральної прокуратури України № 186 від 21 вересня 2018 p. URL: https://www.gp.gov.ua/ua/gl.html?_m=publications\&_ $\mathrm{t}=\mathrm{rec} \& \mathrm{id}=94102$.

10. Про організацію діяльності прокурорів з нагляду за додержанням законів при виконанні судових рішень у кримінальних справах, а також при застосуванні інших заходів примусового характеру, пов'язаних з обмеженням особистої свободи громадян : наказ Генеральної прокуратури України № 161 від 20 квітня 2016 p. URL: https://www.gp.gov.ua/ua/gl.html? $\mathrm{m}=$ publications\&_t $=\mathrm{rec} \& \mathrm{id}=94102$.

\section{Анотація}

Севрук Ю. Г. Правові основи адміністративно-правового забезпечення реалізації функцій прокуратури України. - Стаття.

У науковій публікації досліджуються правові основи адміністративно-правового забезпечення реалізації функцій прокуратури України. Зазначається, що Конституція України чітко визначає функції прокуратури, які деталізовані в Законі України «Про прокуратуру», проте на практиці іх реалізація потребує ще більшої правової деталізації, що зумовлює необхідність ухвалення Генеральною прокуратурою України цілого масиву підзаконних нормативно-правових актів, зокрема наказів. Наказами Генеральної прокуратури України регламентується порядок здійснення окремих повноважень прокурорів у межах визначених функцій, тому значення таких відомчих нормативних актів важко переоцінити, і вони потребують окремого науково аналізу з метою виявлення прогалин, колізій та формулювання конкретних пропозицій щодо їх удосконалення відповідно до принципів права, норм ратифікованих міжнародних актів і положень чинних законів України.

Формулюється висновок про те, що правовою основою адміністративно-правового забезпечення реалізації функції прокуратури є Кримінальний процесуальний кодекс України, Цивільний процесуальний кодекс України, Господарський процесуальний кодекс України, Кодекс адміністративного судочинства України, закони України «Про прокуратуру», «Про організаційно-правові основи боротьби 3 організованою злочинністю», «Про запобігання корупції, «Про виконавче провадження» тощо. Основними адміністративно-правовими засобами забезпечення реалізації функцій прокуратури є накази Генеральної прокуратури України, які деталізуються в наказах керівників регіональних і місцевих прокуратур. Загальний стан адміністративно-правового забезпечення реалізації функцій прокуратури України є задовільним через наявні прогалини в національному законодавстві щодо відсутності відповідальності суб'єктів владних повноважень за невиконання законних вимог (запитів, вказівок) прокурора. Пріоритетним напрямом удосконалення адміністративно-пра- 
вового забезпечення реалізації функцій прокуратури України названо внесення змін до процесуальних кодексів України, Закону України «Про прокуратуру» (щодо повернення інституту законних вимог прокурора, які є обов'язковими для всіх органів, підприємств, установ, організацій, посадових осіб та громадян i виконуються невідкладно або в передбачені законом чи визначені прокурором строки (стаття 8 «Обов'язковість виконання вимог прокурора" Закону України «Про прокуратуру» в редакції до 2014 року), Кодексу України про адміністративні правопорушення щодо посилення відповідальності суб'єктів владних повноважень за невиконання законних вимог прокурора (стаття 185-8 Кодексу України про адміністративні правопорушення).

Ключові слова: прокуратура, функції, публічне обвинувачення, процесуальне керівництво, представництво, інтереси держави, нагляд, адміністративно-правове забезпечення, накази, вказівки, законні вимоги, відповідальність, законність, верховенство права.

\section{Summary}

Sevruk Yu. H. Legal bases of administrative and legal support of realization of functions of prosecutor's office of Ukraine. - Article.

In the scientific publication the administrative and legal support for the implementation of the functions of the Prosecutor's Office of Ukraine are analyzed.

It is noted that the Constitution of Ukraine clearly defines the functions of the prosecutor's office, which are detailed in the Law of Ukraine "On the Prosecutor's Office", but in practice their implementation requires even greater legal detail, which necessitates the adoption by the General Prosecutor's Office of a whole range of subordinate legal acts, in particular. The orders of the Prosecutor General's Office of Ukraine regulate the exercise of individual powers of prosecutors within certain functions, so the importance of such departmental regulations are difficult to overestimate and require separate scientific analysis to identify gaps, conflicts and formulate specific proposals for their improvement in accordance with the principles of law international acts and provisions of applicable laws of Ukraine.

The conclusion is drawn that the legal basis of administrative and legal support for the implementation of the function of the prosecutor's office is the Criminal Procedure Code of Ukraine, Civil Procedure Code of Ukraine, Economic Procedure Code of Ukraine, Code of Administrative Judiciary of Ukraine, Laws of Ukraine: "On Prosecutor's Office", "On Organizational and Legal Basis the fight against organized crime", "On Corruption Prevention", "On Enforcement Proceedings", etc. The main administrative and legal means of ensuring the implementation of the functions of the prosecutor's office are the orders of the Prosecutor General's Office of Ukraine, which are detailed in the orders of heads of regional and local prosecutor's offices. The general state of administrative and legal support for the implementation of the functions of the Prosecutor's Office of Ukraine is satisfactory due to the existing gaps in the national legislation regarding the lack of responsibility of the authorities for failure to comply with the prosecutor's legal requirements (requests, instructions). The priority direction of improving the administrative and legal support of the implementation of the functions of the Prosecutor's Office of Ukraine is called to amend the procedural codes of Ukraine, the Law of Ukraine "On the Prosecutor's Office" (regarding the return of the institution of the legal requirements of the prosecutor, which are mandatory for all bodies, enterprises, institutions, organizations, officials and citizens and are fulfilled without delay or within the deadline set by the law or specified by the prosecutor (Article 8 "Obligation to fulfill the prosecutor's requirements" of the Law of Ukraine "On the Prosecutor's Office" as amended by 2014), the Code of Ukraine on Administrative Offenses with respect to government entities for failure to fulfill legal requirements of the prosecutor (Article 185-8 Code of Ukraine on Administrative Offenses).

Key words: prosecutor's office, functions, public prosecution, procedural leadership, representation, state interests, supervision, administrative and legal support, orders, instructions, legal requirements, responsibility, legality, rule of law. 